\title{
ASPECTS OF THE SUSTAINABLE UTILIZATION OF RENEWABLE ENERGY SOURCES
}

\author{
M. Dombi ${ }^{1}$ - I. Kuti ${ }^{1} \&$ P. Balogh ${ }^{2}$ \\ ${ }^{1}$ University of Debrecen, Centre for Agricultural and Applied Economic Sciences, Faculty of Applied Economics \\ and Rural Development, Institute of Economic Theory \\ ${ }^{2}$ University of Debrecen, Centre for Agricultural and Applied Economic Sciences, Faculty of Applied Economics \\ and Rural Development, Institute of Economic Analytical Methodology and Applied Informatics \\ H-4024 Debrecen Böszörményi út. 138.dombi@agr.unideb.hu
}

\begin{abstract}
The aim of this paper is to analyze the main approaches to sustainability and to present an alternative interpretation for the issues involved in the utilization of RES. The utilization technologies can be described by the average values of several technological parameters. Some significant parameters were chosen which are the most relevant for the issue of sustainability. The group of attributes was composed of these parameters in the analysis, which was conducted by the choice experiment (CE) methodology. The examination of each attributes' influence on the individual's preferences and choices was made possible by this method and the preferences of the relevant experts were determined. The weight of the attributes was defined by experts according to the importance of each attribute regarding RES-based technologies. The importance of sustainability attributes implies the significance of sustainability in the case of RES technologies, which thus highlights the characteristics of the more prosperous technological parameters regarding sustainable development.
\end{abstract}

Keywords: sustainability; renewable energy sources; choice experiment, energy policy

\section{Introduction}

The long-term existence of human civilization is only possible with the harmonization of the environmental, social and economic impacts created by humanity and the opportunities provided by the bio-geosphere; in other words sustainable development. In this process the remodeling of the current energy system is an absolute necessity. The system is not sustainable because of irrational and economic growth based energy demand, the population growth and also the short- and long-run insecurity of the resources. An increase in efficiency, the reform of consumption patterns and the restructuring of the energy system must be targeted simultaneously.

Sustainability requirements at the present level of knowledge can only be met by the renewable energy sources (RES); therefore the role of these resources in the energy system must be increased significantly. The efficiency of energy and environmental policy is a key aspect in this process.

Future development is determined by the prevailing ecological conditions and possibilities. Theoretically, all RES based technologies are sustainable. However, the role of RES technologies in sustainability differs in certain characteristics - these are the sustainability attributes. Identifying this structure of sustainability contributes to the necessary remodeling of the energy system with the support of decision-making, strategic planning and a different administrative approach in the field of energy policy.
Assessing the sustainability of RES has been attempted from many perspectives. Descriptions were used in some studies (Rio - Burguillo, 2008; Rio - Burguillo, 2009; Varga - Homonnai, 2009). Scoring (Lukács, 2009) and ranking (Evans et al., 2009) methods are also possible ways of assessment as well as monetarization (Gács, 2010; Ulbert Takács, 2007) which is a less subjective methodology than the others. The most complex assessment method so far attempted is the "Multi Criteria Decision Making" used by Rideg et al. (2009a; 2009b). The weighting of environmental, social and economic aspects was not defined in this complex valuation although it is a key element of the comparison. The exploration of these weightings is attempted in this study - it is an interpretation of sustainability in the utilization of renewable energy sources.

\section{Materials and methods}

The main goal of the research is to help define energy policy priorities by the exploring the weighting of the different aspects. An economic valuation method, the choice experiment method (CE) was used because of its suitability for evaluating the changes in welfare in comparison to other stated preference methods. This methodology is based on Lancaster's characteristics theory of value and the McFadden's random utility theory.

In order to link actual choices with the theoretical construct utility, the random utility framework is used. 
According to random utility theory the $i$ th respondent is assumed to obtain utility $U_{i j}$ from the $j$ th alternative in choice set C. $U_{i j}$ is supposed to comprise a systematic component $\left(V_{i j}\right)$ and a random error component $\left(\varepsilon_{i j}\right)$ :

$$
\mathrm{U}_{\mathrm{ij}}=\mathrm{V}_{\mathrm{ij}}+\varepsilon_{\mathrm{ij}}
$$

The selection of alternative $h$ by individual $i$ over other alternatives implies that the utility $\left(U_{i h}\right)$ of that alternative is greater than the utility of the other alternatives $j$ :

$$
\mathrm{P}_{\mathrm{ih}}=\operatorname{Prob}\left(\mathrm{V}_{\mathrm{ih}}+\varepsilon_{\mathrm{ih}}>\mathrm{V}_{\mathrm{ij}}+\varepsilon_{\mathrm{ij}}\right)
$$

Assuming that the error components are distributed independently and identically (IID) and follow the Gumbel distribution, the probability that alternative $h$ would be chosen is calculated in the conditional logit model (CL) as

$$
\mathrm{P}_{\mathrm{ih}}=\exp \left[\mu \mathrm{V}_{\mathrm{ih}}\right] / \sum \exp \left[\mu \mathrm{V}_{\mathrm{ij}}\right]
$$

where $\mu$ is a scale parameter which is commonly normalized to 1 for any one dataset. The systematic part of utility of the $j$ th alternative is assumed to be a linear function of the attributes (Mayerhoff et al., 2009). The scope of the CE method is the estimation of utility $\left(\mathrm{V}_{\mathrm{j}}\right)$ connected with the attributes (A) of each alternative chosen by the individual.

$$
\mathrm{V}_{\mathrm{j}}=\mathrm{ASC}_{\mathrm{V}}+\beta_{1} \mathrm{~A}_{1}+\beta_{2} \mathrm{~A}_{2}+\ldots+\beta_{\mathrm{n}} \mathrm{A}_{\mathrm{n}}
$$

ASC is an 'alternative specific constant'. The $\beta$ values are the coefficients associated with each of the attributes (BennettBlamey, 2001). The attribute coefficients $(\beta)$ and the trade-off ratio between the attributes are produced by this methodology. They are presenting the preferences of the respondent and thus of the whole population. The common attributes of the alternatives and their levels are defined prior to the examination.

Parameter estimates from the conditional logit model identify the utility parameters (Louviere et al., 2000), and in the case of a linear utility function, marginal utilities. In particular, the parameter on the Local income level identifies the positive of marginal utility of income. The ratios of the attribute parameters to the parameter on the Local income level give part-worths: the marginal " $m$ HUF/TJ" value associated with a change in the attribute (Burton Pearse, 2002).

The first applications of CE were published in the early 80's in the field of marketing and transport researches (Krajnyik, 2008). As the method developed the range of adaptations was explained. There are many publications in tourism, landscape and ecological economic sciences supported by CE. The energetic sector was analyzed also from ecological point of view firstly by Roe et al. (2001). An application of conjoint analysis was used, the respondents chose between two alternatives. The price, the contact terms, the fuel mix and the air pollu- tion were the attributes. The highest willingness to pay (WTP) (implicit price or trade-off ratio between the price and one of the other attributes) was observable by 'the increase in renewable fuel'. The possible power production investments in Scotland were assessed by Bergmann et al. (2006). Preferences were estimated by the CE method through 219 returned questionnaires relating to attributes of landscape, wildlife, air pollution, employment and the price of electricity. The WTP of 'decrease in air pollution' was the highest. The WTP of employment was surprisingly not significant even at a $10 \%$ level. We expect the labour attribute to be one of the highest level preferences in Hungary. The WTP of the residents of Bath, England was examined by Longo et al. (2008) for promotion of renewable energy sources. The attributes of the $\mathrm{CE}$ analyzed were GHG emissions, blackouts, employment and increases in electricity bills. According to these results the $\beta$ coefficients of the price and the blackouts were negative which is natural with harmful impacts. The WTP for the 'decrease in GHG emissions' was the highest. Korean energy investment alternatives were analyzed by $\mathrm{Ku}$ and Yoo (2010). The attributes used were the same as in (Bergmann et al. 2006) but the results shows slightly higher preferences in the employment attribute. Preferences of constituents regarding different energy policies of Michigan State University were examined by Komarek et al. (2011) during a web-based survey. Attributes of fuel mix, energy conservation effort, carbon emission reduction, year reduction achieved and increase in fees were used. The highest attribute coefficient was observable in the case of emission reduction as well as in the increased proportion of wind and solar energy.

\subsection{Study design}

In any survey completed by $\mathrm{CE}$ the respondents are asked to choose between some (2-4) hypothetic alternatives regarding investments, goods or policies. The attributes and the attribute levels first have to be described. These attributes,

Table 1: Attributes and attribute levels

\begin{tabular}{|l|l|c|}
\hline \multicolumn{1}{|c|}{ ATTRIBUTE } & \multicolumn{1}{|c|}{ DESCRIPTION } & LEVELS \\
\hline $\begin{array}{l}\text { GHG emission (relative to } \\
\text { fossil fuels) }\end{array}$ & $\begin{array}{l}\text { Decrease in GHG emission due to the use of each technology } \\
\text { (LCA approach) in comparison to conventional technology - } \\
\text { relative to fossil fuels (\%). }\end{array}$ & $5 ; 50 ; 80$ \\
\hline Land demand & $\begin{array}{l}\text { Amount of technological demand on land used for } \\
\text { agriculture, forestry or nature conservation, ha/TJ. }\end{array}$ & $2 ; 20$ \\
\hline Energy efficiency & Ratio of used and produced energy (LCA approach, O/I) (\%) & 10,$30 ; 60$ \\
\hline $\begin{array}{l}\text { Other harmful ecological } \\
\text { impacts (relative to fossil } \\
\text { fuels) }\end{array}$ & $\begin{array}{l}\text { Direct and indirect impacts of the utilization (e.g. landscape, } \\
\text { noise pollution), relative to fossil fuels, \% }\end{array}$ & $20 ; 60$ \\
\hline Increase in costs & $\begin{array}{l}\text { Investment and operation costs in comparison to } \\
\text { conventional technology (\%) }\end{array}$ & $5 ; 30 ; 60$ \\
\hline New jobs & $\begin{array}{l}\text { New jobs resulting from utilization of resources by each } \\
\text { technology (persons/100 TJ) }\end{array}$ & $2 ; 10 ; 20$ \\
\hline Local income & $\begin{array}{l}\text { Income realized by local citizens, enterprises or local } \\
\text { government due to utilization (m HUF/TJ) }\end{array}$ & $2 ; 5 ; 15$ \\
\hline
\end{tabular}


which were defined on the basis of the relevant literature are shown on Table 1. The most important environmental, social and economic impacts were collected. They are relevant, easy to understand and useful for policy making.

After the definition of attributes the choice sets were constructed. Every alternative is built up from several combinations of attribute level values. The sum of the possible combinations is the full factorial; in this case it amounts to 972 alternatives. It is impossible to complete this number of choice tasks for the respondents, so the fractional factorial was set in order to significantly decrease significantly the number of alternatives. Following this step 18 alternatives remained and 9 choice sets were based on them. The sets contain two alternatives ('A' and 'B') as well as an alternative 'neither' which represents the continued existence of the current energy system. Figure 1 shows an example of a choice set.

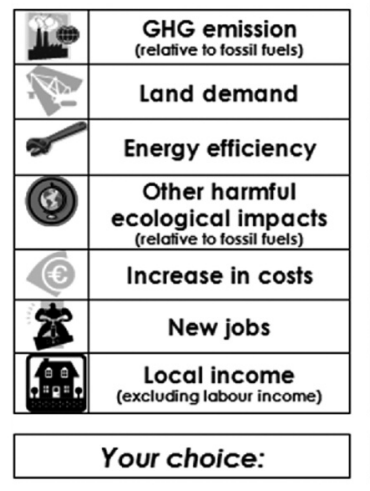

\begin{tabular}{|c|}
\hline $\begin{array}{c}\text { Option } \\
\text { "A" }\end{array}$ \\
\hline $80 \%$ \\
\hline $2 \mathrm{ha}$ \\
\hline $10 \%$ \\
\hline $20 \%$ \\
\hline $30 \%$ \\
\hline 10 \\
\hline $15 \mathrm{M}$ HUF \\
\hline$\square$ \\
\hline
\end{tabular}

\begin{tabular}{|c|}
\hline $\begin{array}{c}\text { Option } \\
\text { B }\end{array}$ \\
\hline $80 \%$ \\
\hline $20 \mathrm{ha}$ \\
\hline $30 \%$ \\
\hline $60 \%$ \\
\hline $30 \%$ \\
\hline 2 \\
\hline $2 \mathrm{M} \mathrm{HUF}$ \\
\hline$\square$ \\
\hline
\end{tabular}

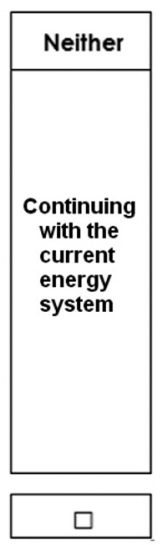

Figure 1: Example choice set

The questionnaire was constructed in three parts. At the beginning there are some easy warm-up questions regarding the knowledge and opinion of the respondent. The second part is the nine choice tasks. After the tasks there are questions in which respondents are asked to state their attitude to the three dimensions of sustainable development.

In the current phase of the research the survey is completed by experts. 172 Hungarian professionals were chosen according to the following criteria. Experts must have a publication on the subject of RES, ecological economics or environmental policy. Professionals who hold a position in governmental bodies, universities or serious NGOs were also considered as experts - even without any publication activity. In this way a database was built up which represents the whole community of the relevant Hungarian experts on the topic. Thus all of the professionals involved were invited to state their opinion. An on-line survey service was used which was available for completion between $11^{\text {th }}$ October and $18^{\text {th }}$ November 2011.52 surveys were received in this time.

\section{Results and discussion}

The survey results regarding the warm-up questions and the experts' attitude are obvious. Every respondent has already heard about sustainability and $98 \%$ of them pointed out that it would be important to have a higher portion of RES in the energy system. The solution of environmental and social problems is more serious and pressing (4.63 and 4.65 on scale of 1-5) than economic problems (4.19) according to respondents' answers. Socio-economic data regarding the experts because was not considered relevant because they were examined by right of their knowledge, and in theory their answers do not vary according to living circumstances and personal conditions.

The estimation results of our model are presented in Table 2. It shows that except for 'energy efficiency' all coefficients are significant at a 95\% level. The signs of every $\beta$ coefficient are consistent with our expectation. The positive signs imply that the experts are more likely to choose a technology which is more efficient, creates new jobs and realizes local incomes. The attributes with a negative sign are connected with harmful impacts. The signs imply the changes in the utility of respondents. For instance when costs increase the utility decreases. On the contrary, the greater the decrease in local incomes the higher the probability of choosing that alternative, hence the utility connected with this attribute.

Table 2: Estimation results of the CL model

\begin{tabular}{|l|c|c|c|c|}
\hline \multicolumn{1}{|c|}{ ATTRIBUTE } & $\begin{array}{c}\beta \\
\text { COEFFICIENT }\end{array}$ & $\begin{array}{c}\text { EXP. } \beta \\
\text { COEF. }\end{array}$ & $\begin{array}{c}\text { STD. } \\
\text { ERROR }\end{array}$ & $p$ \\
\hline ASC & 1.66407 & 5.281 & 0.29079 & $1.00 \mathrm{E}-08^{*}$ \\
\hline GHG emission & -0.01156 & 0.989 & 0.00226 & $3.00 \mathrm{E}-07 *$ \\
\hline Land demand & -0.03243 & 0.968 & 0.00865 & $1.80 \mathrm{E}-04 *$ \\
\hline Energy efficiency & 0.00444 & 1.004 & 0.00434 & $3.10 \mathrm{E}-01$ \\
\hline $\begin{array}{l}\text { Other harmful } \\
\text { ecological impacts }\end{array}$ & -0.01178 & 0.988 & 0.00368 & $1.40 \mathrm{E}-03^{*}$ \\
\hline Increase in costs & -0.01656 & 0.984 & 0.00374 & $9.70 \mathrm{E}-06^{*}$ \\
\hline New jobs & 0.02246 & 1.023 & 0.00959 & $1.90 \mathrm{E}-02 *$ \\
\hline Local income & 0.02835 & 1.029 & 0.01325 & $3.20 \mathrm{E}-02 *$ \\
\hline
\end{tabular}

* significant at $95 \%$ level

Likelihood ratio test $=126$ on $8 \mathrm{df}, \mathrm{p}=0 \mathrm{n}=1404$, number of events $=468$ Exp. $\beta$ coefficient $=\mathrm{e}^{\beta}$

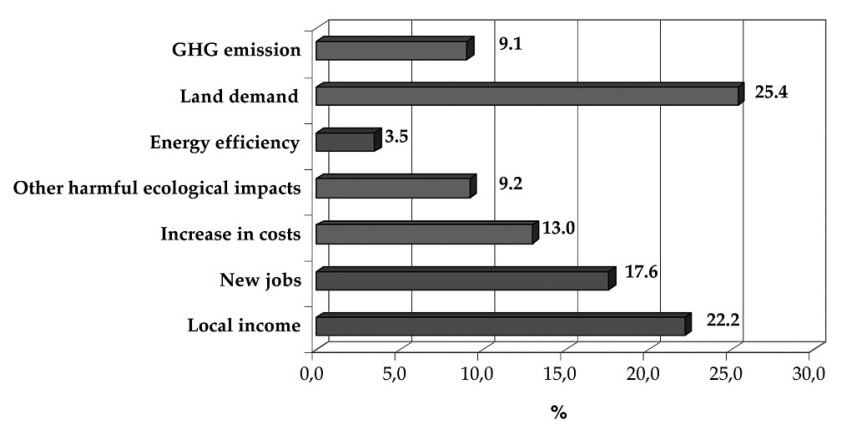

Figure 2: Weighting of sustainability attributes

The exponential coefficients report the changes in utility value of respondents. The exp. coef. implies how much of the change in utility is derived from the variation in levels; for instance, a $1.6 \%(1-0.984)$ decrease is derived from a $1 \%$ 
increase in costs. The $\beta$ coefficient indicates the role of each attribute in the choice made by the population as well as in the utility (see equation (4)). The highest $\beta$ values in absolute terms are observable with land demand (-0.03243) and local income (0.02835). Surprisingly the $\beta$ coefficients in GHG emissions (-0.01156) as well as in other harmful impacts $(-0.01178)$ are low.

Figure 2 reports on the importance of each attribute in decisions. While the experts' task was to choose between alternatives regarding sustainability, we conclude that the role of the attributes in their choices implies the structure of sustainability in the case of RES.

$25.4 \%$ of utility $\left(\beta_{\mathrm{i}} / \sum|\beta|\right)$ is derived by the lower land demand of RES based technology and $22.2 \%$ by retaining income for the local community. The local income and the 'new jobs' (17.6\%) attributes are more important in terms of sustainability than the increase in costs, which constitutes only $13 \%$ of utility. The role of decreasing GHG emissions $(9.1 \%)$ and other harmful ecological impacts $(9.2 \%)$ is low. The very low importance of energy efficiency $(3.5 \%)$ in the structure of sustainability is interesting regarding energy and other development policies.

The attributes used in this study are different from previously used attributes. However, the impact on employment, air pollution and price are common issues. The results of previousr studies are fairly varied. According to $\mathrm{Ku}$ and Yoo (2010) the employment attribute is the most important (35\% of utility value). Longo et al. (2008) reports that the most important factor in the choices was GHG reduction and that other impacts were negligible. The air pollution attribute was found to be the most important by Bergmann et al. (2006).

More attributes were used in this study, and some new impacts were also analyzed. This method did not examine some important issues regarding their role in sustainability for instance the land demand of technologies. Naturally, a new attribute increases the possibilities of choice; a more accurate estimation of utility function is allowed. This is confirmed by the more balanced utility structure of the attributes.

The structure of sustainability in the case of RES based technologies was calculated according to Hungarian experts. The elimination of harmful ecological impacts - emissions and others, as well as the land requirement - would be the most relevant, the 'weight' of these attributes taken together is more than $40 \%$. The energy efficiency is the least significant $(3.5 \%)$. The $\beta$ values for local income and new jobs are much higher than that for the cost attributes. We conclude that the significance of local recourse utilization and welfare is implied, even at the expense of increasing investment and operation costs. The weight of the utilization technologies of RES is already known. Based on the experts' opinion it can be concluded that the elimination of harmful environmental impacts, the increase of local incomes and job creation possibilities are the key aspects on the path to sustainable energy management.

\section{References}

Bennett, J. - Blamey, R. (Eds.). (2001): The Choice Modelling Approach to Environmental Valuation. Edward Elgar. Cheltenham, $287 \mathrm{p}$.

Bergmann, A. - Hanley, N. - Wright, R. (2006): Valuing the attributes of renewable enery investments. Energy Policy, 34. pp. 1004-1014.

Burton, M., - Pearse, D. (2002): Consumer attitudes towards genetic modification, functional foods, and microorganisms: A Choice modeling experiment for beer. AgBioForum, 5(2). pp. 51-58.

del Rio, P. - Burguillo, M. (2008): Assessing the impact of renewable energy deployment on local sustainability: towards a theoretical framework. Renewable \& Sustainable Energy Reviews, 12. pp. 1325-1344.

del Rio, P. - Burguillo, M. (2009): An empirical analysis of the impact of renewable energy deployement on local sustainability. Renewable \& Sustainable Energy Reviews, 13. pp. 1314-1325.

Evens, A. - Strezov, V. - Evans, T. J. (2009): Assessment of sustainability indicators for renewable energy technologies. Renewable \& Sustainable Energy Reviews, 13. pp. 1082-1088.

Gács I. (2010). A szélenergia-termelés támogatása. Elektrotechnika. 1. pp. 5-7.

Komarek, T. M. - Lupi, F. - Kaplowitz, M. D. (2011): Valuing energy policy attributes for environmental management: Choice experiment evidence from a research institution. Energy Policy, 39. pp. 5105-5115.

Krajnyik, Zs. (2008): Környezeti javak pénzbeli értékelése Magyarországon és Szlovákiában a feltételes választás módszerének alkalmazásával. PhD értekezés. Budapesti Corvinus Egyetem. 169 p.

Ku, S. - Yoo, S. (2010): Willingness to pay for renewable energy investment in Korea: A choice experiment study. Renewable and Sustainable Energy Reviews, 14. pp. 2196-2201.

Longo, A. - Markandya, A. - Petrucci, M. (2008): The internalization of externalities in the production of electricity: Willingness to pay for the attributes of a policy for renewable energy. Ecological Economics, 67. pp. 140-152.

Lukács, G. S. (2009): Megújuló energia és vidékfejlesztés. Budapest: Szaktudás Kiadó Ház. 265 p.

Louviere, J.J. - Hensher, D.A. - Swait, J.D. (2000): Stated choice methods: Analysis and applications. Cambridge, UK: Cambridge University Press.

Mayerhoff, J. - Liebe, U. - Hartje, V. (2009): Benefits of biodiversity enhancement of nature-oriented silviculture: Evidence from two choice experiments in Germany. Journal of Forest Economics, 15. pp. 37-58.

Rideg, A. - Deutsch, N. - Torjai, L. (2009a): Biogázüzem telepítésének többszempontú értékelése. Energiagazdálkodás, 3. pp. 26-29.

Rideg, A. - Deutsch, N. - Torjai, L. (2009b): Háztartási hasznosítású napkollektoros és h szivattyús beruházás többszempontú értékelése. Magyar Épületgépészet, 7-8. pp. 6-10.

Roe, B. - Teisl, M. F. - Levy, A. - Russell, M. (2001): US consumers' willingness to pay for green electricity. Energy Policy, 29. pp. 917-925.

Varga, K. - Homonnai, G. (2009): Munkahelyteremtés zöld energiával. Budapest: Energia Klub. 17 p.

Ulbert, J. - Takács, A. (2007): Energetikai beruházások társadalmi hasznosságának mérése. Via Futuri 2007. Pécs 